\title{
LONG-LIVED BANANA ORBIT FORMATION OF SUPRATHERMAL ELECTRONS DURING MHD SPIKES IN RUNAWAY TOKAMAK DISCHARGES
}

\author{
Igor Pankratovi,2, (DVolodymyr Bochko' \\ ${ }^{1}$ Department of Physics and Technology, V.N. Karazin Kharkiv National University \\ Svobody Sq.4, 61022 Kharkiv, Ukraine \\ ${ }^{2}$ Institute of Plasma Physics, NSC "Kharkiv Institute of Physics and Technology" \\ Akademichna Str.1, 61108 Kharkiv, Ukraine \\ E-mail:pankratov@kipt.kharkov.ua \\ Received May 29, 2019; revised August 7, 2019; accepted August 21, 2019
}

\begin{abstract}
The secondary runaway electrons generation is the process in which already existing high energy runaway electrons knock out thermal plasma electrons directly into the runaway region by close Coulomb collisions. Such knocked-on electrons are immediately accelerated to ultrarelativistic velocities, since in the runaway region the toroidal electric field force overcomes the collisional friction force with thermal plasma particles. The avalanche of runaway electrons with mega-electron-volt energy emerges, hit of which with the construction elements of large-scale tokamaks and future international tokamak ITER can lead to catastrophic consequences. Due to its importance, this phenomenon is being actively studied both theoretically and experimentally in leading thermonuclear fusion centers. It is known that during secondary generation, the value of the transversal component of knocked-on electrons momentum with respect to the confining magnetic field may be significantly higher than the longitudinal one: $p_{\perp}>>p_{\|}$. Thus, conditions for knocked-on electron trapping in a non-uniform tokamak magnetic field occur (banana orbits). Such electrons can no longer be accelerated by the inducted toroidal electric field to high energies, avalanche formation is partially suppressed. The question is how long this population of knocked-on and trapped electrons exists. In the presented paper, it is shown the additional possibility of formation and existence of such long-lived banana orbits of suprathermal electrons under conditions of plasma MHD activity when MHD instability spikes induced the strong burst of the toroidal electric field that results in the abrupt growth in these knocked-on and trapped electrons. This phenomenon is considered for the recent low-density EAST (Institute of Plasma Physics, Chinese Academy of Sciences, Hefei, China) tokamak quasistationary runaway discharges. Long-lived trapped electrons $\left(p_{\perp}>>p_{\|}\right)$also have an influence on the intensity of ECE emission. The considered phenomenon is important for correct interpretation of the runaway experiments on present-day tokamaks.
\end{abstract}

KEYWORDS: tokamak, runaway electrons, suprathermal electrons, banana orbits, electron cyclotron emission (ECE)

The runaway electrons during major disruptions can cause serious damage to plasma-facing-component surfaces in large tokamaks like ITER $[1,2]$. The strong electric fields induced during the tokamak disruptions can generate many runaways (REs). The energy of these REs can reach as high as tens of MeV. Due to close Coulomb collisions of these REs with the electrons of the background plasma, the effect of avalanche occurs (secondary runaway generation) [3].

The knocked-on secondary electrons may have significant transverse momentum, $p_{\perp}>>p_{\|}\left(p_{\|}\right.$and $p_{\perp}$ are longitudinal and transversal components of momentum with respect to the confining magnetic field, correspondingly). In tokamaks, electrons trapped in a non-uniform tokamak magnetic field may appear in this case [4]. As the result of close collisions, the formation of long-lived trapped suprathermal electron population under conditions of working gas (deuterium) puffing during runaway tokamak discharges (DIII-D runaway experiments under quiescent conditions [5]) was investigated in $[6,7]$.

In the present paper, it is shown the additional possibility of long-lived banana orbit formation of suprathermal electrons during MHD spikes in runaway tokamak discharges (EAST experiments [8-10]). This is the objective of this investigation.

\section{RUNAWAY EAST DISCHARGE WITH THE STEPWISE JUMP INCREASES OF THE NON-THERMAL ECE SIGNAL DURING MHD BURSTS}

During EAST experiments with runaway electrons [8-10], peculiar events have been investigated: rapid changes in the synchrotron spot shape and its intensity that coincided with step-like jumps in the electron cyclotron emission (ECE) signal (cyclotron radiation of suprathermal electrons) and the MHD $(m / n=2 / 1)$ Mirnov signal spikes ( $m$ and $n$ are the poloidal and toroidal mode numbers, respectively). These phenomena were initially observed in TEXTOR (Tokamak Experiment for Technology Oriented Research), where these events only occurred in the current decay phase or in discharges with thin stable runaway beams at the $q=1$ drift surface [11] ( $q$ is the safety factor).

The runaway ohmic discharge \#28957 in EAST was performed in the limiter configuration with the toroidal magnetic field $B_{0}=2 \mathrm{~T}$, the plasma current $I_{\mathrm{p}}=250 \mathrm{kA}$, the inductive equilibrium electric field $E_{\|}=V_{\text {loop }} / 2 \pi R_{0}=E_{0} \approx 0.1 \mathrm{~V} / \mathrm{m}$, the central line-averaged density $\left.<n_{\mathrm{e}}\right\rangle=2.210^{19} \mathrm{~m}^{-3}$, the plasma major radius $R_{0}=1.86 \mathrm{~m}$ and the minor radius $a=0.45 \mathrm{~m}$ [8-10]. At the plasma center, the electron temperature $T_{\mathrm{e}} \approx 0.55 \mathrm{keV}$ was obtained using a soft $\mathrm{x}$-ray pulse height analysis (PHA) system during the plasma current flat-top phase (duration of impulse was $5 \mathrm{~s}$ ). MHD modes $m / n=1 / 1$ (the soft $\mathrm{x}$-ray signal) and $m / n=2 / 1$ (the Mirnov coil signals) existed in the plasma. Runaway electrons were created by the ohmic coil during the start-up phase of the discharge, the runaway 
current was significant. The runaway electrons were located near the $q=2$ rational magnetic surface at $r \approx(20-30) \mathrm{cm}$ (ring-like runaway electron beam).

In shot \#28957 three types of events were observed with the stepwise jump increases of the non-thermal ECE signal that are described and discussed in details in Refs. [8-10]. Here, we give only a short summary of these papers results:

1. The MHD $(m / n=2 / 1)$ small amplitude spikes (type I events, small non-thermal ECE jumps) emerged approximately every $0.02 \mathrm{~s}$ and coincided with sawtooth $m / n=1 / 1$ peaks.

2. Huge MHD spikes (type II events) emerged approximately every $0.5 \mathrm{~s}$.

3. Larger amplitude MHD $(m / n=2 / 1)$ spikes (type III events) were observed approximately every $0.3 \mathrm{~s}$ after each huge MHD spike (type II events).

In cases II-III types events the MHD $(m / n=2 / 1)$ spikes of the non-thermal ECE jumps were not small. In these cases, MHD spikes were not correlated with the $m / n=1 / 1$ sawtooth oscillations peaks.

These ECE jumps were visible in the ECE channels, which should receive the second harmonic X-mode emission of the thermal electrons from the tokamak low-field-side (lfs).

Due to the local runaway generation processes, local changes in the plasma current density profile should occur (around the $q=2$ rational magnetic surface, where the runaway electrons are located). In [10] it has been shown that these local changes in the current density profile are a possible trigger for enhancement of magnetohydrodynamic (MHD) tearing mode activity and fast changes in runaway beam behavior. For these shots, the MHD $m / n=2 / 1$ bursts were resulted from tearing mode instability with induced bursts of the strong electric field during magnetic reconnections.

In low-density plasma $\left(n_{\mathrm{e}} \sim 10^{19} \mathrm{~m}^{-3}\right)$, the occurrence of runaway electrons is connected to their continuous acceleration by the tokamak toroidal equilibrium electric field $E_{\|}=E_{0} \approx 0.1 \mathrm{~V} / \mathrm{m}$. The runaway energy $E_{\text {run }} \approx 30 \mathrm{MeV}$ was deduced from a joint analysis of the synchrotron radiation spectra and the synchrotron radiation spot shape in EAST discharge \#28957 [9]. This means that in EAST discharge \#28957, the secondary runaway generation process should take place (runaway avalanche).

\section{D MOMENTUM-SPACE ANALYSIS OF SUPRATHERMAL ELECTRON GENERATION}

The generation of both high-energy runaway and suprathermal electrons should be enhanced abruptly during these MHD spikes. Because of the fast changes in the magnetic flux (squeezing and reconnection of the magnetic field lines) the bursts of induced electric fields, $E_{\|}(t)$, occurred [12]. The value of $E_{\|}(t)$ may reach values of an order of ten V/m. During these bursts of the induced electric field $E_{\|}(t)$, the avalanche process was enhanced with corresponding avalanching time [13]

$$
t_{a v} \approx \sqrt{12} m_{e} c L\left(2+Z_{e f f}\right) / 9 e E_{\|}(t) .
$$

The electron runaway region increased very fast because of the value of parameter (this key parameter determines boundaries of runaway region)

$$
p_{c r}^{2}\left(E_{\|}(t)\right)=e^{3} m_{e} n_{e} L / 4 \pi \varepsilon_{0}^{2} E_{\|}(t)
$$

dropped during the burst of $E_{\|}(t)$ (Fig. 1), e, $m_{\mathrm{e}}$ are the charge and rest mass of electron, respectively, $L$ is the Coulomb logarithm.

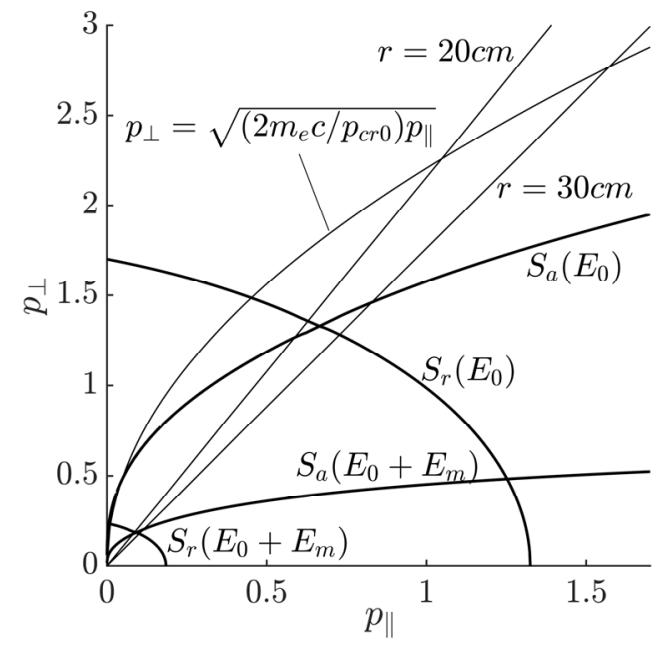

Fig. 1. The evolution of runaway region in 2D plane $\left(p_{\|}, p_{\perp}\right)$ during MHD burst.

The abrupt growth in the suprathermal electron population occurred during these bursts of $E_{\|}$. In $[10,14]$ conclusion was made that the step-like non-thermal ECE jumps may be explained by the abrupt growth in the 
suprathermal electron generation (number of runaways) during MHD $m / n=2 / 1$ spikes. In Fig. 1 the evolution of runaway region in $2 \mathrm{D}$ plane $\left(p_{\|}, p_{\perp}\right)$ is shown. Normalized variables are used:

$$
E_{\|}(t) \rightarrow E_{\|}(t) / E_{0}, p_{\|, \perp} \rightarrow p_{\|, \perp} / p_{c r}\left(E_{0}\right), t \rightarrow t / \tau_{b r} .
$$

Here $S_{\mathrm{r}}\left(E_{0}, E_{0}+E_{\mathrm{m}}\right)$ and $S_{\mathrm{a}}\left(E_{0}, E_{0}+E_{\mathrm{m}}\right)$ are separatrixes (compare with $\left.[13,15]\right)$ for plasma parameters at $E_{0}$ and $E_{0}+E_{\mathrm{m}}$, where $E_{\mathrm{m}}$ is the maximum amplitude of the toroidal electric field during MHD spike, $\tau_{\mathrm{br}} \sim 1 \mathrm{~ms}$ is the time during which the value of electric field changes from $E_{0}$ to $E_{0}+E_{\mathrm{m}}$. This analysis is based on the equations (compare with [13, 15]):

$$
\begin{gathered}
\frac{d p_{\|}}{d t}=\tau_{b r} \frac{e E_{\|}(0)}{p_{c r 0}}\left(E_{\|}(t)-\left(Z_{e f f}+2\right) \frac{p_{\|}}{\left(p_{\|}^{2}+p_{\perp}^{2}\right)^{3 / 2}}\right), \\
\frac{d p_{\perp}^{2}}{d t}=2 \tau_{b r} \frac{e E_{\|}(0)}{p_{c r 0}} \frac{1}{\sqrt{p_{\|}^{2}+p_{\perp}^{2}}}\left(\left(Z_{e f f}+2\right) \frac{p_{\|}^{2}}{p_{\|}^{2}+p_{\perp}^{2}}-1\right) .
\end{gathered}
$$

The first term in expression (4) describes the test electron's acceleration by $E_{\|}(t)$, and the second one describes the frictional force due to collisions of this electron with thermal particles. The total momentum (kinetic energy) of the test electron also changes due to $e \boldsymbol{E} \boldsymbol{v}$ term and collisions that leads to change of transversal component of momentum: expression (5). The runaway region lies just above the separatrix $S_{\mathrm{r}}$. Electrons situated above $S_{\mathrm{r}}$ lie on trajectories aiming asymptotically outward along $S_{\mathrm{a}}$ and therefore run away. In Fig. $1 E_{0}=0.1 \mathrm{~V} / \mathrm{m}$, as example the value $E_{\mathrm{m}}=5 \mathrm{~V} / \mathrm{m}$ is used. Note, the value $E_{\mathrm{m}}=12 \mathrm{~V} / \mathrm{m}$ of the induced electric field was found during a series of minor disruptions in the T-10 tokamak [16].

Note that in accordance with the conservation laws of energy and momentum, the knocked-on electrons of secondary generation are arranged on elongated ellipses, the major axes of which are equal to the momentum of the incident mega-electron-volt electrons. Secondary runaway region in the phase space $\left(p_{\|}, p_{\perp}\right)$ is filled by these ellipses. In case of EAST shot \#28957 the ring-like runaway beam contained high energy electrons with energy more than $20 \mathrm{MeV}$ and $p_{\perp} / p_{\|} \sim 0.15\left(p_{\|}>p_{\perp}\right)[8,9]$. The bulk electrons knocked out in runaway region by these very high energy electrons are born near the parabola [4]:

$$
p_{\perp}=\sqrt{\left(2 m_{e} c / p_{c r 0}\right) p_{\|}} .
$$

This curve (6) is shown in Fig. 1, the locus of the knocked-on electrons lies below this curve. The suprathermal electron population with $p_{\perp}>p_{\|}$occurs. These electrons may be trapped in a non-uniform tokamak magnetic field $\left(\varepsilon=r / R_{0}\right)$

$$
B(r, \theta)=\frac{B_{0}}{1-\varepsilon \cos \theta},
$$

if the inequality

$$
p_{\perp} / p_{\|}>1 / \sqrt{2 \varepsilon}
$$

holds at poloidal angle $\theta=\pi$. In Fig. 1, straight lines

$$
p_{\perp} / p_{\|}=1 / \sqrt{2 \varepsilon}
$$

are shown for the values of $r=20 \mathrm{~cm}$ and $r=30 \mathrm{~cm}$. The entire range of locus of the knocked-on electrons in 2D plane $\left(p_{\|}, p_{\perp}\right)$ lies above straight lines of Eq. (9). It is necessary to distinguish situation on the outer (lfs) and inner sides of the tokamak discharge. The trapped suprathermal electrons may appear in the lfs region, only.

In Fig. 2 narrow banana orbits of the trapped suprathermal electrons are shown for the radii $r=20 \mathrm{~cm}$ and $r=30 \mathrm{~cm}$. Recall, the ring-like runaway electron beam were located near the $q=2$ value at these $r=(20-30) \mathrm{cm}[8,9]$.

The calculations were carried out on the base of the well-known equations of motion of a charged particle in nonuniform tokamak magnetic field (see, e.g. [17], $\omega_{\mathrm{B}}=e B_{0} / m_{\mathrm{e}}$ ):

$$
\begin{gathered}
\frac{d r}{d t}=\frac{v_{\|}^{2}+0.5 v_{\perp}^{2}}{\left|\omega_{B}\right| R_{0}} \sin \theta, \\
r \frac{d \theta}{d t}=v_{\|} \frac{r}{q R_{0}(1-\varepsilon \cos \theta)}+\frac{v_{\|}^{2}+0.5 v_{\perp}^{2}}{\left|\omega_{B}\right| R_{0}} \cos \theta .
\end{gathered}
$$

More strong losses of these trapped electrons may occur from the plasma region where these electrons are located (outer part of discharge). It is even possible formation of supertrapped electrons (on the ripples of a toroidal magnetic field) which immediately escape from the plasma owing to toroidal drift. 
For considered energy of suprathermal electrons, the time-scale for pitch-angle equilibration (isotropization process) is much shorter than the momentum evolution time-scale [18]. The time-scale during which banana orbits may exist is much shorter in comparison with the isotropization time $\tau_{\text {coll. }}$.

The pitch angle that corresponds to banana orbits existence, Eq. (8), was taken into account in the estimation of the value of $\tau_{\text {effcoll }}$

$$
\tau_{\text {effcoll }}=\tau_{\text {coll }} 2 \varepsilon /(1+2 \varepsilon)
$$

and well-known expression for $\tau_{\text {coll }}$ is used:

$$
\tau_{\text {coll }}^{-1}=e^{4} n_{e} m_{e} L / 4 \pi \varepsilon_{0}^{2}\left(p_{\perp}^{2}+p_{\|}^{2}\right)^{3 / 2} .
$$

Note that the value of ion effective charge $Z_{\text {eff }}$ was not high in shot \#28957.
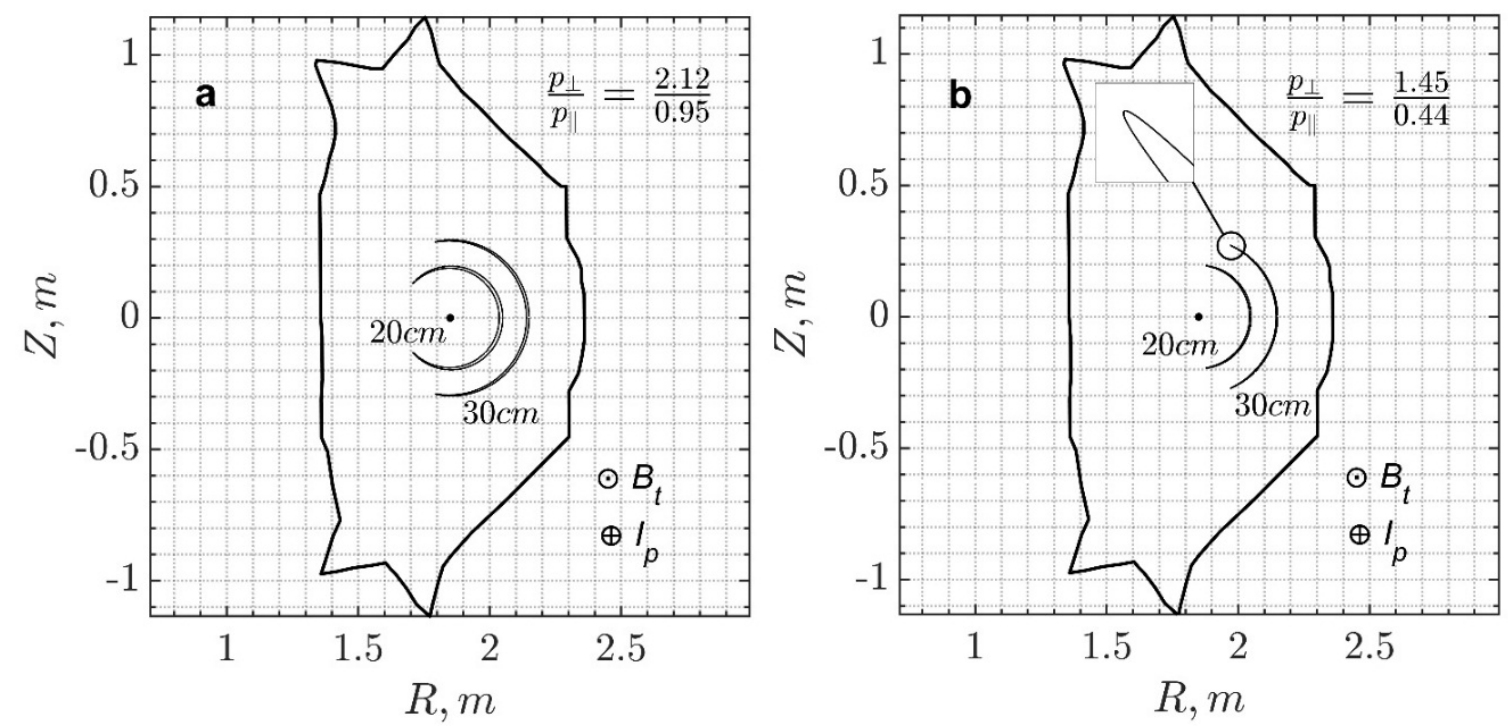

Fig. 2. Narrow banana orbits of suprathermal electrons

a) banana width (1.0-1.4) $\mathrm{cm}$, energy $\sim 230 \mathrm{keV}$; b) banana width $(0.5-0.7) \mathrm{cm}$, energy $\sim 100 \mathrm{keV}$. The values of $p_{\perp}$ and $p_{\|}$ corresponds to point at $\theta=\pi$. Directions of the toroidal magnetic field and plasma current are shown.

In Fig. 3, comparison of the bounce period of trapped suprathermal electrons $\left(T_{\mathrm{b}}<1 \mu \mathrm{s}\right)$ with the effective collision time shows that $T_{\mathrm{b}}<<\tau_{\text {effcoll }}$. The long-lived banana orbits of suprathermal electrons have arisen. Ratio $\tau_{\text {effcoll }} / T_{\mathrm{b}}$ can reach about five orders of magnitude. However, for $p_{\|} \lesssim 0.1$ the value of $\tau_{\text {effcoll }}$ decreases fast and $\tau_{\text {effcoll }} \rightarrow T_{\mathrm{b}}$. In this region, the possibility of long-lived banana orbit formation is lower. The energy of suprathermal electrons corresponding to $p_{\|}=0.1$ is about $20 \mathrm{keV}$. For calculation of $\tau_{\text {coll }}$ the values of $p_{\perp}$ were chosen close (but below) to the parabola of Eq. (6).

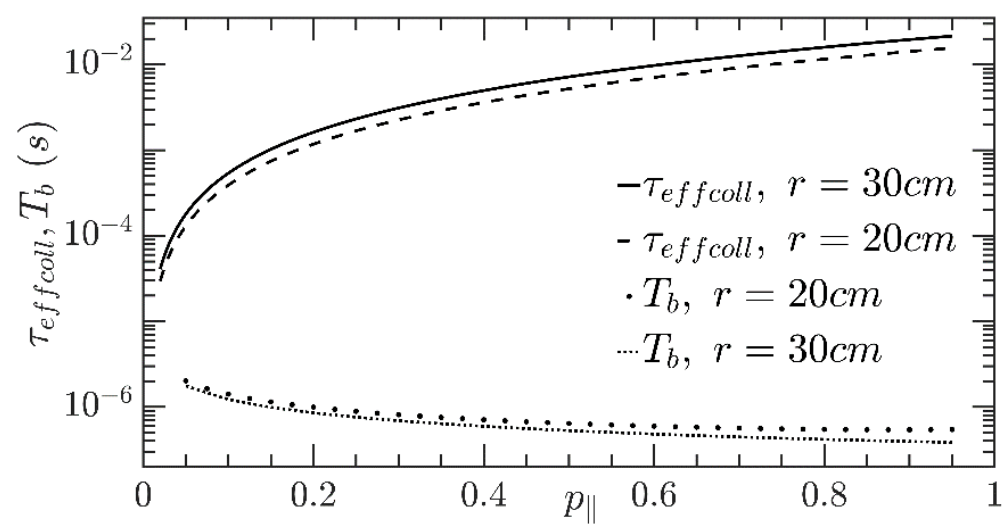

Fig. 3. The bounce period, $T_{\mathrm{b}}$, of trapped suprathermal electrons and the effective collision time, $\tau_{\text {effcoll. }}$

In the EAST case, trapped knock-on secondary electrons were created far enough from the magnetic axis. These trapped electrons drift radially inwards due to the Ware pinch effect [19]

$$
\frac{d r}{d t}=-\frac{E_{\|}(t)}{B_{\theta}}
$$


here $B_{\theta}$ is the poloidal magnetic field. They may be detrapped and run away (compare with [20]). Because of a very short time of the MHD spikes, the linear time dependence of changes of the bursting electric field $E_{\|}(t)$ was taken for integration of Eq. (14).

For analysis of the time $\Delta \mathrm{t}_{\mathrm{W}}$, required for a trapped electron to become passing (during the MHD burst), we obtain the next equation:

$$
\left(\frac{\Delta t_{W}}{\tau_{b r}}\right)^{2}+2\left(\frac{E_{0}}{E_{m}}+\frac{t_{0}}{\tau_{b r}}\right)\left(\frac{\Delta t_{W}}{\tau_{b r}}\right)-2 \frac{\Delta r_{W}}{\tau_{b r} E_{m} / B_{\theta}}=0,
$$

where $\Delta r_{\mathrm{W}} \sim(5-10) \mathrm{cm}$ is the required radial displacement for detrapping process, $\tau_{\mathrm{br}} \sim 1 \mathrm{~ms}, t_{0}=t_{\mathrm{br} 0}-t_{\mathrm{b} 0}$, here $t_{\mathrm{br} 0}$ corresponds to the start of the burst, $t_{\mathrm{b} 0}$ is the time when the banana was born, $B_{\theta} \approx 0.1 \mathrm{~T}$. Even for the value of $E_{\mathrm{m}}=10 \mathrm{~V} / \mathrm{m}$ from Eq. (9) we get $\Delta t_{W} \sim 1 \mathrm{~ms}$, that means $\Delta t_{W}>>T_{\mathrm{b}}$.

\section{CONCLUSIONS}

The formation of long-lived knocked-on and trapped suprathermal electrons (long-lived banana orbits) in nonuniform magnetic field during MHD spikes in tokamak runaway discharges is shown, because of the effective collision frequency of these trapped electrons with background plasma particles is much smaller in comparison with the oscillation frequency of the bounce motion of trapped suprathermal electrons. The MHD spikes acted as a trigger for the enhancement of additional suprathermal electron generation (because of bursts of the toroidal electric field) during magnetic reconnections.

Such electrons can no longer be accelerated by the inducted toroidal electric field to high energies. The avalanching (secondary runaway generation) process may be suppressed in part.

The observed stepwise increases in the non-thermal electron cyclotron emission (ECE) signal coincided with the spikes of the MHD activity confirm abrupt growth of suprathermal electrons, and stepwise form of this signal may be explained by the existence of these long-lived knocked-on and trapped electrons population. The intensity of ECE signal must be strongly enhanced due to the existence of the long-lived suprathermal electron population with a high value of transversal momentum $\left(p_{\perp}>p_{\|}\right)$.

The energy domain of these suprathermal electrons is shifted to more high values; in considered case, it is higher than $20 \mathrm{keV}$. The RE distribution function changes in this region of energies may be expected.

The considered phenomenon is important for correct interpretation of the runaway experiments.

\section{ACKNOWLEDGEMENTS}

We thank Dr. R.J. Zhou for detail discussions of EAST runaway experiments presented in the paper.

\section{ORCID IDs}

Igor Pankratov https://orcid.org/0000-0001-5876-4618, Volodymyr Bochko $\mathbb{D}$ https://orcid.org/0000-0003-2109-968X

\section{REFERENCES}

[1] ITER Physics Basis, Chapter 3: MHD stability, operational limits and disruptions, Nucl. Fusion 39, 2175 (1999), DOI: $10.1088 / 0029-5515 / 39 / 12 / 303$.

[2] Progress in the ITER Physics Basis, Nucl. Fusion 47, S128 (2007), DOI: 10.1088/0029-5515/47/6/S03.

[3] Yu. A. Sokolov, JETP Letters, 29, 218 (1979).

[4] N.T. Besedin and I.M. Pankratov, Nucl. Fusion, 26, 807 (1986), DOI 10.1088/0029-5515/26/6/009.

[5] C. Paz-Soldan, N.W. Eidietis, R. Granetz, E.M. Hollman, R.A. Moyer, J.C. Wesley, J. Zhang, M.E. Austin, N.A. Crocker, A. Wingen, and Y. Zhu, Phys. Plasmas, 21, 022514 (2014), DOI: 10.1063/1.4866912.

[6] I.M. Pankratov and V.Y. Bochko, in: Proceedings of the 45th EPS Conf. on Plasma Phys. (Prague, 2018), P2.1057.

[7] I.M. Pankratov and V.Y. Bochko, Problems of Atomic Science and Technology, Series: Plasma Physics, 6(118), 8-11 (2018), in: https://vant.kipt.kharkov.ua.

[8] R.J. Zhou, L.Q. Hu, E.Z. Li, M. Xu, G.Q. Zhong, L.Q. Xu, S.Y. Lin, J.Z. Zhang and the EAST Team, Plasma Phys. Control. Fusion, 55, 055006 (2013), DOI: 10.1088/0741-3335/55/5/055006.

[9] R.J. Zhou, I.M. Pankratov, L.Q. Hu, M. Xu and J.H. Yang, Phys. Plasmas, 21, 063302 (2014), DOI: 10.1063/1.4881469.

[10] I.M. Pankratov, R.J. Zhou and L Q. Hu, Phys. Plasmas, 22, 072115 (2015), DOI: 10.1063/1.4927578.

[11] R. Jaspers, Relativistic Runaway Electrons in Tokamak Plasmas, Ph.D. thesis (Eindhoven University of Technology, The Netherlands, 1995), in: http://repository.tue.nl/431410.

[12] D. Biskamp, Magnetic Reconnection in Plasmas (Cambridge: Cambridge University Press, 2000).

[13] I.M. Pankratov, R. Jaspers, K.H. Finken and I. Entrop, in: Proceedings of the 26th EPS Conf. on Contr. Fusion and Plasma Physics, (Maastricht, 1999), p. 597.

[14] Yu. M. Marchuk and I.M. Pankratov, Problems of Atomic Science and Technology, Series: Plasma Physics, 1(107) 6 (2017), in: https://vant.kipt.kharkov.ua.

[15] V. Fuchs, R.A. Cairns, C.N. Lashmore-Davies and M.M. Shoucri, Phys. Fluids, 29, 2931 (1986), DOI: 10.1063/1.865493.

[16] P.V. Savrukhin and E.A. Shestakov, Nucl. Fusion, 55, 043016 (2015), DOI: 10.1088/0029-5515/55/4/043016.

[17] Б.Б. Кадомцев, О.П. Погуце, Турбулентные проиессы в тороидальных системах, в сб.: Вопросы теории плазмы, вып. 5, под ред. М.А. Леонтовича (М.: Атомиздат, 1967); В.В. Kadomtsev and O.P. Pogutse, Turbulence in Toroidal Systems, in: Reviews of Plasma Physics, 5, edited by M.A. Leontovich (Boston: Springer, 1970). 
[18] В.В. Параил, О.П. Погуце, Ускоренные электроны в токамаке, в сб.: Вопросы теории плазмы, вып. 11, под общ. ред. М. А. Леонтовича и Б.Б. Кадомцева (М.: Энергоиздат, 1982); V.V. Parail and O.P. Pogutse, Runaway electrons in a tokamak, in: Reviews of Plasma Physics, 11, edited by M. A. Leontovich and B. B. Kadomtsev (New York: Consultant Bureau, 1986).

[19] A.A. Ware, Phys. Rev. Lett. 25, 916 (1970), DOI: 10.1103/PhysRevLett.25.916.

[20] E. Nilsson, J. Decker, N.J. Fisch and Y. Peysson, J. Plasma Physics, 81, 475810403 (2015), DOI: 10.1017/S0022377815000446.

\section{ОБРАЗОВАНИЕ ДОЛГОЖИВУЩИХ БАНАНОВЫХ ОРБИТ НАДТЕПЛОВЫХ ЭЛЕКТРОНОВ ВО ВРЕМЯ ВСПЫШЕК МГД АКТИВНОСТИ В РАЗРЯДАХ ТОКАМАКА С УБЕГАЮЩИМИ ЭЛЕКТРОНАМИ И.М. Панкратов ${ }^{1,2}$, В.Ю. Бочко ${ }^{1}$ \\ ${ }^{1}$ Физико- технический факультет, Харьковский национальный университет имени В.Н. Каразина пл. Свободы 4, 61022 Харьков, Украина \\ ${ }^{2}$ Институт физики плазмы, ННЦ “Харьковский физико- технический институт” ул. Академическая 1, 61108 Харьков, Украина}

Вторичная генерация убегающих электронов - это процесс, при котором уже существующие высокоэнергетические убегающие электроны выбивают тепловые электроны плазмы непосредственно в область убегания в результате близких кулоновских столкновений. Такие выбитые электроны мгновенно ускоряются до ультрарелятивистских скоростей поскольку, в области убегания сила со стороны тороидального электрического поля значительно превосходит силу трения обусловленную кулоновскими столкновениями с тепловыми частицами плазмы. Возникает лавина мегаэлектронвольтных убегающих электронов, попадание которых на элементы конструкции современных больших токамаков и строящегося международного токамака-реактора ИТЭР может привести к катастрофическим последствиям. В силу своей актуальности, в настоящее время это явление широко изучается как теоретически, так и экспериментально в ведущих термоядерных центрах. Известно, что при вторичной генерации у выбитых электронов величина перпендикулярного импульса по отношению к магнитному полю токамака может существенно превышать продольную компоненту: $p_{\perp}>>p_{\|}$. Таким образом возникают условия захвата выбитых электронов неоднородным магнитным полем токамака (банановые орбиты). Захваченные электроны уже не могут ускорятся индукционным тороидальным электрическим полем до высоких энергий, лавинообразование убегающих электронов частично подавляется. Возникает вопрос, как долго такая популяция выбитых и захваченных надтепловых электронов существует. В данной работе показана дополнительная возможность для формирования и существования долгоживущих банановых орбит надтепловых электронов в условия МГД активности плазмы, когда во время вспышек МГД неустойчивости индуцируется сильное тороидальное электрическое поле что и приводит к резкому росту таких выбитых и захваченных электронов. Это явление рассмотрено для недавних экспериментов c убегающими электронами на токамаке EAST (Институт физики плазмы, Хефей, Академия наук Китая) в квазистационарных разрядах с низкой плотностью. Долгоживущие захваченные электроны $\left(p_{\perp}>>p_{\|}\right)$также оказывают влияние на интенсивность ЕСЕ излучения. Рассмотренное явление важно для правильной интерпретации экспериментов с убегающими электронами на современных токамаках.

КЛЮЧЕВЫЕ СЛОВА: токамак, убегающие электроны, надтепловые электроны, банановые орбиты, электронное циклотронное излучение (ЕСЕ)

\section{ФОРМУВАННЯ ДОВГОЖИВУЧИХ БАНАНОВИХ ОРБІТ НАДТЕПЛОВИХ ЕЛЕКТРОНІВ ПІД ЧАС СПАЛАХІВ МГД АКТИВНОСТІ В РОЗРЯДАХ ТОКАМАКА 3 ЕЛЕКТРОНАМИ-ВТІКАЧАМИ І.М. Панкратов ${ }^{1,2}$, В.Ю. Бочко ${ }^{1}$}

${ }^{l}$ Фізико- технічний факультет, Харківський національний університет імені В.Н. Каразіна м. Свободи 4, 61022 Харків, Україна

${ }^{2}$ Інститут фізики плазми, ННЦ “Харківський фізико-технічний інститут” вул. Академічна 1, 61108 Харків, Украӥна

Вторинна генерація електронів-втікачів - це процес, під час якого існуючі високоенергетичні втікаючі електрони вибивають теплові електрони плазми безпосередньо в область втікання в результаті близьких кулонівських зіткнень. Такі вибиті електрони миттєво прискорюються до ультрарелятивістських швидкостей, тому що в області втікання сила прискорення тороїдальним електричним полем значно перевищує силу тертя внаслідок кулонівських зіткнень 3 тепловими частинками плазми. Виникає лавина мегаелектронвольтних електронів-втікачів, потрапляння яких на конструкційні елементи сучасних великомасштабних токамаків і міжнародного споруджуваного токамака-реактора ITEP може призвести до катастрофічних наслідків. Внаслідок своєї актуальності, у теперішній час дане явище активно досліджується як теоретично, так і експериментально у провідних термоядерних центрах. Відомо, що при вторинній генерації у вибитих електронів величина перпендикулярної компоненти імпульсу по відношенню до магнітного поля токамака може значно перевищувати повздовжню компоненту: $p_{\perp}>p_{\|}$. Таким чином, виникають умови захоплення вибитих електронів неоднорідним магнітним полем токамака (бананові орбіти). Захоплені електрони більше не можуть прискорюватися індукованим електричним полем до високих енергій, лавиноподібне утворення електронів-втікачів частково пригнічується. Виникає питання, як довго популяція вибитих і захоплених надтеплових електронів існує. У даній роботі показана додаткова можливість для формування та існування довгоживучих бананових орбіт надтеплових електронів в умовах МГД активності плазми, коли під час спалахів МГД нестійкості індукується сильне тороїдальне електричне поле, що призводить до різкого зростання кількості таких вибитих і захоплених електронів. Дане явище розглянуто для нещодавніх експериментів 3 електронамивтікачами на токамаці EAST (Інститут фізики плазми, Хефей, Академія наук Китаю) в квазістаціонарних розрядах 3 низькою щільністю плазми. Довгоживучі захоплені електрони ( $\left.p_{\perp}>p_{\|}\right)$також впливають на інтенсивність ЕСЕ випромінювання. Розглянуте явище важливе для правильної інтерпретації експериментів 3 електронами-втікачами на сучасних токамаках.

КЛЮЧОВІ СЛОВА: токамак, електрони-втікачі, надтеплові електрони, бананові орбіти, електронне циклотронне випромінювання (ЕСЕ) 